\title{
Cloacibacterium rupense sp. nov., isolated from freshwater lake sediment
}

\author{
Shu-Juan Cao, Chun-Ping Deng, Bao-Zhen Li, Xiu-Qin Dong \\ and Hong-Li Yuan
}

Correspondence

Hong-Li Yuan

hlyuan@cau.edu.cn

\begin{abstract}
State Key Laboratories for AgroBiotechnology, College of Biological Sciences, China Agricultural University, Beijing 100193, PR China
\end{abstract}

\begin{abstract}
A Gram-negative, yellow-pigmented bacterium, designated strain $R 2 A-16^{\top}$, was isolated from sediment of Rupa Lake in Nepal and analysed using a polyphasic taxonomic approach. Phylogenetic analyses based on $16 \mathrm{~S}$ rRNA gene sequences showed that strain R2A-16 ${ }^{\top}$ is affiliated to the genus Cloacibacterium of the family Flavobacteriaceae; 16S rRNA gene sequence similarity between strain R2A $-16^{\top}$ and Cloacibacterium normanense CCUG $46293^{\top}$ was $98.07 \%$. The isolate contained iso- $\mathrm{C}_{15: 0}(35.6 \%)$ as the major fatty acid and menaquinone MK- 6 as the predominant respiratory quinone. The $\mathrm{G}+\mathrm{C}$ content of the genomic DNA was $33.3 \mathrm{~mol} \%$. On the basis of its phenotypic properties and phylogenetic distinctiveness, strain $\mathrm{R} 2 \mathrm{~A}-16^{\top}$ represents a novel species of the genus Cloacibacterium, for which the name Cloacibacterium rupense sp. nov. is proposed; the type strain is R2A-16 ${ }^{\top}$ (=CGMCC $1.7656^{\top}$ $=$ NBRC $104931^{\top}$ ).
\end{abstract}

The genus Cloacibacterium of the family Flavobacteriaceae was created by Allen et al. (2006) and currently comprises a single species, Cloacibacterium normanense. During studies of the bacterial diversity of sediment of Rupa Lake located in southern Nepal, a novel bacterium, strain R2A-16 ${ }^{\mathrm{T}}$, was isolated. Strain $\mathrm{R} 2 \mathrm{~A}-16^{\mathrm{T}}$ was considered to be a Cloacibacterium-like strain based on the results of the $16 \mathrm{~S}$ rRNA gene sequence analysis. The aim of this study was to describe the exact taxonomic position of strain R2A- $16^{\mathrm{T}}$ using a polyphasic taxonomic approach.

Strain R2A- $16^{\mathrm{T}}$ was isolated on R2A agar incubated at $37{ }^{\circ} \mathrm{C}$ for $48 \mathrm{~h}$. The recommended media and growth conditions were used to culture $C$. normanense DSM $15886^{\mathrm{T}}$ (Allen et al., 2006), used as a reference strain. Cell morphology of both strains was determined using cells grown on R2A medium. For fatty acid methyl ester analysis, strain R2A-16 ${ }^{\mathrm{T}}$ was cultivated on tryptic soy agar (Difco) at $37{ }^{\circ} \mathrm{C}$ for $24 \mathrm{~h}$ for direct comparison with reference strains. Cell biomass for quinone analysis and for DNA extraction was obtained from cultures in liquid R2A medium. The Gram reaction was assessed as described by Gerhardt et al. (1994) and by the $\mathrm{KOH}$ lysis method (Gregersen, 1978). Flexirubin-type pigments were detected according to the method of Fautz \& Reichenbach (1980). Further pigment analysis was performed as described by

The GenBank/EMBL/DDBJ accession number for the $16 \mathrm{~S}$ rRNA gene sequence of strain R2A-16 ${ }^{\top}$ is EU581834.

Maximum-parsimony and minimum-evolution 16S rRNA gene sequencebased phylogenetic trees are available as supplementary material with the online version of this paper.
Allen et al. (2006). Catalase activity was determined by means of bubble production in a $3 \%(\mathrm{v} / \mathrm{v})$ hydrogen peroxide solution. Oxidase activity was determined from the oxidation of $1 \% p$-aminodimethylaniline oxalate. Hydrolysis of starch was tested on starch agar (Difco). Nitrate reduction and hydrolysis of casein, aesculin, urea, DNA and gelatin were examined according to Dong \& Cai (2001). The $\mathrm{pH}$ range and optimum was determined according to the method of Allen et al. (2006). Tests for carbohydrate utilization were performed in a liquid medium containing $2.0 \mathrm{~g}\left(\mathrm{NH}_{4}\right)_{2} \mathrm{SO}_{4}, 0.5 \mathrm{~g} \mathrm{NaH} \mathrm{NO}_{4}$, $0.5 \mathrm{~g} \mathrm{~K}_{2} \mathrm{HPO}_{4}, 0.2 \mathrm{~g} \mathrm{MgSO}_{4}, 0.02 \%$ (w/v) yeast extract and $0.5 \%(\mathrm{w} / \mathrm{v})$ carbohydrate dissolved in 11 distilled water. Media were incubated at $<37{ }^{\circ} \mathrm{C}$ and $30{ }^{\circ} \mathrm{C}$ for strains R2A- $16^{\mathrm{T}}$ and $\mathrm{NRS1}^{\mathrm{T}}$, respectively, and results were determined spectrophotometrically by testing $\mathrm{OD}_{660}$ after 3 days. Other tests, including anaerobic growth, antibiotic sensitivity and characteristics listed in Table 1 and the species description, were performed according to Dong \& Cai (2001); C. normanense DSM $15886^{\mathrm{T}}$ was also tested as a control.

For quantitative analysis of cellular fatty acid composition, fatty acid methyl ester mixtures were prepared and identified following the manufacturer's instructions for the Microbial Identification System (MIDI, 2002) and identified by using the Microbial Identification software package (Sasser, 1990). For analysis of isoprenoid quinones, cells grown aerobically were freeze-dried and the lipid fraction was extracted according to Collins (1985) and analysed by HPLC as described by Groth et al. (1997). Genomic DNA was prepared according to the method of 
Table 1. Differential characteristics of strain $R 2 A-16^{\top}$ and $C$. normanense DSM $15886^{\top}$

Data for C. normanense DSM $15886^{\mathrm{T}}$ match those reported by Allen et al. (2006) unless indicated.

\begin{tabular}{|lcc|}
\hline Characteristic & R2A-16 & C. normanense DSM $^{\mathbf{T}} \mathbf{1 5 8 8 6}^{\mathbf{T}}$ \\
\hline Colony pigmentation & Yellow & Light yellow $^{*}$ \\
Motility & + & - \\
Anaerobic growth & - & + \\
Optimal growth temperature & 37 & 30 \\
( $\left.{ }^{\circ} \mathrm{C}\right)$ & & \\
Hydrolysis of: & - & $+{ }^{*}$ \\
DNA & - & + \\
Casein & - & + \\
Production of: & + & - \\
Indole & & + \\
Urease & - & + \\
Sensitivity to: & - & 31.0 \\
Carbenicillin & 33.3 & Municipal \\
Tetracycline & Lake sediment & wastewater \\
DNA G+C content (mol\%) & & \\
Isolation source & & \\
& &
\end{tabular}

${ }^{\star}$ Reported as yellow (colony pigmentation) and weak (DNA hydrolysis) by Allen et al. (2006).

Marmur (1961). The $\mathrm{G}+\mathrm{C}$ content was analysed by the thermal denaturation method using a BIO-20 UV spectrophotometer according to De Ley et al. (1970). For the calculation of DNA G + C content, the equation of De Ley et al. (1970) was used and corrected using genomic DNA of Escherichia coli K-12 as a reference. DNA-DNA hybridization experiments were carried out spectrophotometrically (De Ley et al., 1970).

The 16S rRNA gene fragment of strain R2A- $16^{\mathrm{T}}$ was amplified using individual bacterial colony PCR (Güssow \& Clackson, 1989). The primers used for PCR were 27F (5'-GAGAGTTTGATCCTGGCTCAG) and 1495R (5'-CTACGGCTACCTTGTTACGA) (E. coli numbering; Brosius et al., 1978). PCR products were sequenced using DNA Sequencer 3730 with the software provided by the manufacturer (Applied Biosystems). An almost-complete 16S rRNA gene sequence was compared initially with reference sequences in GenBank using BLAST (Altschul et al., 1997).

Sequence alignments were carried out using CLUSTAL W version 1.8 (Thompson et al., 1994). Similarities (\%) were calculated by the method of Jukes \& Cantor (1969) in the program CLUSTAL W. Phylogenetic analysis of multiple sequence alignments was performed with MEGA version 3.1 (Kumar et al., 2004). Phylogenetic tree construction was carried out by using the neighbour-joining (Saitou \& Nei, 1987), minimum-evolution (Rzhetsky \& Nei, 1993) and maximum-parsimony (Kluge \& Farris, 1969) methods.
Details of the cultural, physiological and biochemical characteristics of strain $\mathrm{R} 2 \mathrm{~A}-16^{\mathrm{T}}$ are given in the species description and in Table 1 . The cellular fatty acid profile of strain $\mathrm{R} 2 \mathrm{~A}-16^{\mathrm{T}}$ was characterized by the predominance of iso- $\mathrm{C}_{15: 0}(35.6 \%)$ and was similar to that of $C$. normanense $\mathrm{NRS1}^{\mathrm{T}}$. However, R2A- $16^{\mathrm{T}}$ differed from C. normanense $\mathrm{NRS1}^{\mathrm{T}}$ in containing $\mathrm{C}_{14: 0}, \mathrm{C}_{15: 0} 2-\mathrm{OH}, \mathrm{C}_{16: 0}, \mathrm{C}_{18: 0}$ and summed feature 3 and lacking $\mathrm{C}_{12: 0} 3-\mathrm{OH}, \mathrm{C}_{16: 0} 3-\mathrm{OH}$ and $\mathrm{C}_{16: 1} \omega 5 c$ (Table 2). The predominant respiratory quinone was menaquinone MK-6. The DNA G $+\mathrm{C}$ content was $33.3 \mathrm{~mol} \%$. DNA-DNA hybridization between the novel isolate and C. normanense DSM $15886^{\mathrm{T}}$ was $17 \%$.

The almost-complete 16S rRNA gene sequence (1399 bp) of strain R2A-16 ${ }^{\mathrm{T}}$ was determined. $16 \mathrm{~S}$ rRNA gene sequence similarity between $\mathrm{R} 2 \mathrm{~A}-16^{\mathrm{T}}$ and $C$. normanense CCUG $46293^{\mathrm{T}}$ was $98.07 \%$. Sequence similarities with all other species of the family Flavobacteriaceae included in the phylogenetic analysis were below $94.7 \%$. In the phylogenetic tree based on the neighbour-joining algorithm, strain R2A$16^{\mathrm{T}}$ clustered with C. normanense CCUG $46293^{\mathrm{T}}$ (Fig. 1). Similar tree topologies were also found in trees generated with the maximum-parsimony and minimum-evolution

Table 2. Cellular fatty acid composition of strain $R 2 A-16^{\top}$ and C. normanense $\mathrm{NRS}^{\top}{ }^{\mathrm{T}}$

Values are percentages of total fatty acids. -, Not detected or less than $1 \%$. Data for C. normanense $\mathrm{NRS1}^{\mathrm{T}}$ were taken from Allen et al. (2006)

\begin{tabular}{|c|c|c|}
\hline Fatty acid & R2A-16 ${ }^{\mathrm{T}}$ & $\begin{array}{c}\text { C. normanense } \\
\mathrm{NRS1}^{\mathrm{T}}\end{array}$ \\
\hline $\mathrm{C}_{12: 0} 3-\mathrm{OH}$ & - & 2.1 \\
\hline iso- $\mathrm{C}_{13: 0}$ & 3.0 & 7.9 \\
\hline anteiso- $\mathrm{C}_{13: 0}$ & - & 1.1 \\
\hline iso- $\mathrm{C}_{14: 0}$ & 1.8 & 3.3 \\
\hline $\mathrm{C}_{14: 0}$ & 1.5 & - \\
\hline $\mathrm{C}_{15: 0}$ & 1.7 & 1.1 \\
\hline iso- $\mathrm{C}_{15: 0}$ & 35.6 & 40.8 \\
\hline anteiso- $\mathrm{C}_{15: 0}$ & 8.7 & 5.0 \\
\hline $\mathrm{C}_{15: 0} 2-\mathrm{OH}$ & 1.0 & - \\
\hline iso- $\mathrm{C}_{15: 0} 3-\mathrm{OH}$ & 5.4 & 3.5 \\
\hline iso- $\mathrm{C}_{15: 1}$ & 5.0 & 7.8 \\
\hline anteiso- $\mathrm{C}_{15: 1}$ & 5.4 & 5.4 \\
\hline $\mathrm{C}_{16: 0}$ & 2.7 & - \\
\hline iso- $\mathrm{C}_{16: 0}$ & 1.4 & 1.7 \\
\hline $\mathrm{C}_{16: 0} 3-\mathrm{OH}$ & - & 1.0 \\
\hline iso- $\mathrm{C}_{16: 0} 3-\mathrm{OH}$ & 2.1 & 2.5 \\
\hline $\mathrm{C}_{16: 1} \omega 5 c$ & - & 1.0 \\
\hline iso- $\mathrm{C}_{17: 0} 3-\mathrm{OH}$ & 7.7 & 5.3 \\
\hline $\mathrm{C}_{18: 0}$ & 2.4 & - \\
\hline Summed feature $3^{\star}$ & 6.2 & - \\
\hline
\end{tabular}

* Summed features are combinations of fatty acids that cannot be separated by the MIDI system. Summed feature 3 comprises iso- $\mathrm{C}_{15: 0}$ 2-OH and/or $\mathrm{C}_{16: 1} \omega 7 c$. 


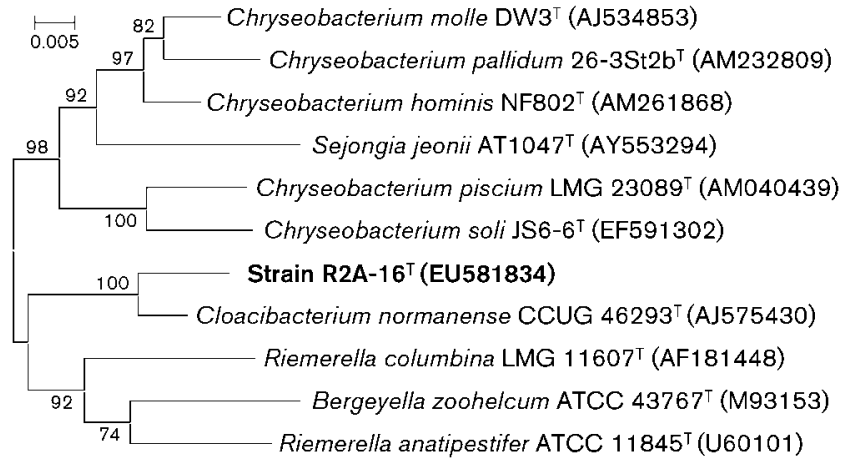

Fig. 1. Neighbour-joining tree showing the phylogenetic position of strain R2A-16 ${ }^{\top}$, C. normanense CCUG $46293^{\top}$ and other reference strains based on $16 \mathrm{~S}$ rRNA gene sequences. Bootstrap values, expressed as percentages of 1000 replications, greater than $50 \%$ are shown at branch points. Bar, 0.005 substitutions per nucleotide position.

algorithms (available as Supplementary Fig. S1 in IJSEM Online).

The above-mentioned chemotaxonomic features, together with the morphological, physiological and biochemical characteristics, strongly support the classification of strain R2A- $16^{\mathrm{T}}$ within the genus Cloacibacterium. Its phylogenetic distinctiveness is sufficient to categorize strain $\mathrm{R} 2 \mathrm{~A}-16^{\mathrm{T}}$ as a representative of a novel species within the genus Cloacibacterium (Allen et al., 2006). On the basis of the results obtained, strain $\mathrm{R} 2 \mathrm{~A}-16^{\mathrm{T}}$ is sufficiently distinct from C. normanense to be recognized as a representative of a novel species of the genus Cloacibacterium, for which the name Cloacibacterium rupense sp. nov. is proposed.

\section{Description of Cloacibacterium rupense sp. nov.}

Cloacibacterium rupense (ru.pen'se. N.L. neut. adj. rupense pertaining to Rupa, the name of the lake in Nepal where the type strain was isolated).

On R2A agar, cells are $0.2-0.3 \times 1.0-2.0 \mu \mathrm{m}$, Gramnegative, non-sporulating, motile, straight rods, occurring singly, in pairs or in long chains. Colonies grown on agar medium are yellow, round, convex, entire, waxy and semitransparent. Colony diameter is $1-2 \mathrm{~mm}$ after incubation for $48 \mathrm{~h}$ at $37{ }^{\circ} \mathrm{C}$. Strictly aerobic. The optimum $\mathrm{pH}$ for growth is 7 (range pH 5.5-8.5). The optimum temperature for growth is $37^{\circ} \mathrm{C}$ (range $18-37^{\circ} \mathrm{C}$ ). Catalase- and oxidase-positive. Negative for nitrate reduction. Starch, gelatin, urea and aesculin are hydrolysed, but casein, DNA and Tween 80 are not. Negative for indole production and methyl red and Voges-Proskauer tests. Pigment is not of the flexirubin type. Yellow carotenoid-type pigment is produced. Resistant to streptomycin $(10 \mu \mathrm{g})$, kanamycin $(30 \mu \mathrm{g})$, tetracycline $(30 \mu \mathrm{g})$ and carbenicillin $(100 \mu \mathrm{g})$; sensitive to chloramphenicol $(30 \mu \mathrm{g})$ and ampicillin $(10 \mu \mathrm{g})$. The following carbohydrates can be used as sole carbon sources: D-ribose, D-mannose, L-arabinose, Dglucose, cellobiose, lactose, maltose, sucrose, D-salicin, Lrhamnose, D-galactose, starch, D-arabinose and D-xylose. D-Fructose, raffinose, inulin, D-sorbitol, inositol, melezitose, L-rhamnose, sodium gluconate, glycerol, trehalose and D-mannitol are not used. Major cellular fatty acids are iso- $\mathrm{C}_{15: 0}$, anteiso- $\mathrm{C}_{15: 0}$ and iso- $\mathrm{C}_{17: 0} 3-\mathrm{OH}$. Predominant respiratory quinone is $\mathrm{MK}-6$.

The type strain is R2A-16 ${ }^{\mathrm{T}}$ (=CGMCC $1.7656^{\mathrm{T}}=\mathrm{NBRC}$ $104931^{\mathrm{T}}$ ), isolated from sediment of Rupa Lake in southern Nepal. The DNA G+C content of the type strain is $33.3 \mathrm{~mol} \%$.

\section{Acknowledgements}

This work was supported by a project from the Chinese National Natural Science Foundation (nos 30670071 and J0730639), the Special Program for Water Pollution Control of Taihu Lake in Jiangsu Province, China (no. BK2007741) and the Chinese Universities Fund (2009-3-09).

\section{References}

Allen, T. D., Lawson, P. A., Collins, M. D., Falsen, E. \& Tanner, R. S. (2006). Cloacibacterium normanense gen. nov., sp. nov., a novel bacterium in the family Flavobacteriaceae isolated from municipal wastewater. Int J Syst Evol Microbiol 56, 1311-1316.

Altschul, S. F., Madden, T., Schäffer, A. A., Zhang, J., Zhang, Z., Miller, W. \& Lipman, D. J. (1997). Gapped BLAST and PSI-BLAST: a new generation of protein database search programs. Nucleic Acids Res 25, 3389-3402.

Brosius, J., Palmer, J. L., Kennedy, J. P. \& Noller, H. F. (1978). Complete nucleotide sequence of a $16 \mathrm{~S}$ ribosomal RNA gene from Escherichia coli. Proc Natl Acad Sci U S A 75, 4801-4805.

Collins, M. D. (1985). Isoprenoid quinone analysis in classification and identification. In Chemical Methods in Bacterial Systematics, pp. 267-287. Edited by M. Goodfellow \& D. E. Minnikin. London: Academic Press.

De Ley, J., Cattoir, H. \& Reynaerts, A. (1970). The quantitative measurement of DNA hybridization from renaturation rates. Eur $J$ Biochem 12, 133-142.

Dong, X.-Z. \& Cai, M.-Y. (editors) (2001). Determination of biochemical properties. In Manual for the Systematic Identification of General Bacteria, pp. 370-398. Beijing: Science Press (in Chinese).

Fautz, E. \& Reichenbach, H. (1980). A simple test for flexirubin-type pigments. FEMS Microbiol Lett 8, 87-91.

Gerhardt, P., Murray, R. G. E., Wood, W. A. \& Krieg, N. R. (editors) (1994). Methods for General and Molecular Bacteriology. Washington, DC: American Society for Microbiology.

Gregersen, T. (1978). Rapid method for distinction of Gram-negative from Gram-positive bacteria. Eur J Appl Microbiol Biotechnol 5, 123127.

Groth, I., Schumann, P., Rainey, F. A., Martin, K., Schuetze, B. \& Augsten, K. (1997). Demetria terragena gen. nov., sp. nov., a new genus of actinomycetes isolated from compost soil. Int J Syst Bacteriol 47, 1129-1133.

Güssow, D. \& Clackson, T. (1989). Direct clone characterization from plaques and colonies by the polymerase chain reaction. Nucleic Acids Res 17, 4000. 
Jukes, T. H. \& Cantor, C. R. (1969). Evolution of protein molecules. In Mammalian Protein Metabolism, vol. 3, pp. 21-132. Edited by H. N. Munro. New York: Academic Press.

Kluge, A. G. \& Farris, J. S. (1969). Quantitative phyletics and the evolution of anurans. Syst Zool 18, 1-32.

Kumar, S., Tamura, K. \& Nei, M. (2004). MEGA3: integrated software for molecular evolutionary genetics analysis and sequence alignment. Brief Bioinform 5, 150-163.

Marmur, J. (1961). A procedure for the isolation of deoxyribonucleic acid from microorganisms. J Mol Biol 3, 208-218.

MIDI (2002). MIS Operating Manual, version 4.5. Newark, DE: MIDI, Inc.
Rzhetsky, A. \& Nei, M. (1993). Theoretical foundation of the minimum-evolution method of phylogenetic inference. Mol Biol Evol 10, 1073-1095.

Saitou, N. \& Nei, M. (1987). The neighbor-joining method: a new method for reconstructing phylogenetic trees. Mol Biol Evol 4, 406425.

Sasser, M. (1990). Identification of bacteria by gas chromatography of cellular fatty acids, MIDI Technical Note 101. Newark, DE: MIDI Inc.

Thompson, J. D., Higgins, D. G. \& Gibson, T. J. (1994). CLUSTAL W: improving the sensitivity of progressive multiple sequence alignment through sequence weighting, position-specific gap penalties and weight matrix choice. Nucleic Acids Res 22, 4673-4680. 